\title{
José Yvan Leite, o Editor
}

Neste primeiro editorial da Revista Holos após o redimensionamento desse periódico, prestamos uma homenagem póstuma ao nosso editor José Yvan Leite. Como editor comprometido com a editoração de publicações científicas, ele realizou um trabalho excepcional, primando sempre pela qualidade nos aspectos técnicos, éticos e científicos. Com seriedade e competência, elevou a novos patamares de desenvolvimento o trabalho editorial de divulgação da ciência no âmbito do Instituto Federal de Educação, Ciência e Tecnologia do Rio Grande do Norte/IFRN e se tornou referência profissional para os demais colegas editores, sobretudo na região Nordeste do Brasil.

Por essa razão, ainda sentidos por sua partida repentina, todos que fazem o IFRN, comunidade acadêmica e científica, servidores e estudantes, além de editores de periódicos no país e ao redor do mundo, não hesitam em lhe render honras e prestigiar sua memória. Todos reconhecem a projeção que este periódico alcançou graças a seus esforços editoriais, legando ao IFRN e à comunidade científica um periódico cadastrado em bases de dados e indexadores de excelência. Além disso, incorporou ao longo dos anos a fidelidade de autores de vários outros países, como Cuba, Chile, Espanha, Irã, México, Portugal, Reino Unido, entre outros, assim como cativou leitores em várias partes do mundo: Angola, Colômbia, Equador, Espanha, Estados Unidos, México, Moçambique, Peru, só para citar alguns países que aparecem em nossas estatísticas de acesso.

Neste ano, a Revista Holos alcançou o Qualis A3 na avaliação de meio-termo dos periódicos realizada pela Capes, a qual considerou os anos de 2017 e 2018, em que os periódicos foram avaliados por uma única área de referência, sendo Educação a área-mãe da Holos. Este é um importante marco para o periódico o qual está ladeado de mais 43 no mesmo estrato, ou seja, o correspondente a 8,7\%. Esse feito, infelizmente, não chegou ao conhecimento de José Yvan, mas temos plena convicção de que, como editor, buscou incansavelmente esse resultado com muita consciência do trabalho realizado.

José Yvan também sempre esteve atento aos acontecimentos do país e do mundo no que toca ao cenário político e educacional, como também às repercussões de tais fatos no campo científico, ao mesmo tempo em que demonstrava sua defesa pela educação e ciência para todos. Por isso, neste ano, marcado por cortes e condições de financiamento do Conselho Nacional de Desenvolvimento Científico e Tecnológico (CNPq) e da Coordenação de Aperfeiçoamento de Pessoal de Nível Superior (Capes), o que pode comprometer a educação e a ciência no país, nosso editor não se furtava a opinar de modo consciente.

Nos editoriais que José escrevia para a Holos, ao lado de suas itinerâncias geográficas e científicointelectuais, os leitores puderam acompanhar um editor coerente, sensível às causas sociais e educacionais de nosso povo e que se mostrava firme em seus posicionamentos políticos, porquanto bastante antenado com os problemas da sociedade. Não apenas neste editorial, como em todo este primeiro volume da Revista Holos de 2019, que ora apresentamos à comunidade científica, há muito do trabalho realizado pelo editor José Yvan Leite em cada artigo, o que deverá ainda acontecer nos demais volumes que seguirão em fluxo contínuo.

Para concluir, manifestamos, mais uma vez, nossa gratidão ao Professor José Yvan Leite e reforçamos nosso convite à leitura e à colaboração na divulgação da produção científica veiculada neste periódico, além de reiterarmos nosso compromisso com a busca pela manutenção da qualidade alcançada pela Revista Holos, visando consolidá-la como periódico de referência na área.

Natal-RN, 3 de dezembro de 2019. 
Francinaide de Lima Silva Nascimento

Fábio Augusto Procópio de Paiva

Kadydja Karla Nascimento Chagas

Leandro Silva Costa

Márcio Adriano de Azevedo

Nadir Arruda Skeete

Olívia de Medeiros Neta

Rafael Hernandez Damascena dos Passos

Rodrigo Luiz Silva Pessoa 